\title{
PENGAMATAN STRUKTUR MIKRO PADA KOROSI ANTAR BUTIR DARI MATERIAL BAJA TAHAN KARAT AUSTENITIK SETELAH MENGALAMI PROSES PEMANASAN
}

\author{
ANWAR BUDIANTO*, KRISTINA PURWANTINI*, BA.TJIPTO SUJITNO ** \\ "Sekolah Tinggi Teknologi Nuklir - BATAN \\ Jl. Babarsari, Kotak Pos 6101 YKBB Yogyakarta 55281, \\ E-MAIL:TAUFAD@YAHOO.COM \\ *** Pusat Teknologi Akselerator dan Proses Bahan - BATAN, \\ Jl. Babarsari, Kotak Pos 6101 YKBB, Yogyakarta, 55281.
}

\begin{abstract}
Abstrak
PENGAMATAN STRUKTUR MIKRO PADA KOROSI ANTAR BUTIR DARI MATERIAL BAJA TAHAN KARAT AUSTENITIK SETELAH MENGALAMI PROSES HEAT PEMANASAN. Telah dilakukan pengamatan korosi antar butir pada material baja tahan karat austenitik jenis SS 304 setelah mengalami proses perlakuan panas (heat treatment) pada selang suhu $(400-950){ }^{\circ} \mathrm{C}$ dengan variasi waktu pemanasan (holding time) yaitu 1 jam, 3 jam, 3,5 jam, dan 4 jam. Sebelum dan sesudah proses perlakuan panas, struktur mikro sampel dianalisis menggunakan mikroskop optik dan SEM (Scanning Electron Microscope). Komposisi kimia pada daerah di sekitar batas butir diamati menggunakan SEM-EDS (Energy Dispersive X-ray Spectrometer). Hasil pengamatan menunjukkan bahwa sampel yang mengalami perlakuan panas di bawah suhu sensitisasi yakni pada suhu $400{ }^{\circ} \mathrm{C}$, ternyata korosi antar butir tidak teramati. Untuk sampel yang mengalami perlakuan panas pada suhu sensitisasi yakni pada selang suhu (500-900) ${ }^{\circ} \mathrm{C}$, ternyata korosi antar butir dapat teramati dengan jelas. Sedangkan untuk sampel yang mengalami perlakuan panas di atas suhu sensitisasi yaitu pada suhu $950{ }^{\circ} \mathrm{C}$, ternyata korosi antar butir masih dapat teramati tetapi tidak sejelas sampel yang mengalami perlakuan panas pada suhu sensitisasi. Dari analisis komposisi kimia di sekitar batas butir ditemukan adanya penurunan kandungan karbon (C) yaitu dari 0,61\% massa menjadi $0,47 \%$ massa, dan untuk khrom $(\mathrm{Cr})$ dari $18,37 \%$ massa menjadi $17,76 \%$ massa.
\end{abstract}

Kata kunci : korosi antar butir, austentitik, perlakuan panas, struktur mikro, mikroskop optik, SEM-EDS.

\footnotetext{
Abstract

MICRO STRUCTURE OBSERVATION OF INTERGRANULAR CORROSION OF AUSTENITIC STAINLESS STEEL MATERIAL AFTER HEAT TREATMENT PROCESS. Observation of the intergranular corrosion of austenitic stainless steel material SS-304 type has been done by heating process
} 
treatment under temperature range of $(400-950){ }^{\circ} \mathrm{C}$ which holding time variation of 1 , $3,3.5$ and 4 hours have been carried out. Before and after heating process, the microstructures of the samples were analyzed using optical microscope and SEM (Scanning Electron Microscope). The chemical composition of the grain boundaries was analyzed using EDS (Energy Dispersive X-Ray Spectrometer) coupled with SEM. The results show that after heat process treatment under sensitization temperature of $400{ }^{\circ} \mathrm{C}$ the intergranular corrosion is not clear. While for treated samples at sensitization temperature range of (500-900) ${ }^{\circ} \mathrm{C}$, the intergranular corrosion observed clearly. For samples heated above sensitization temperature around $950{ }^{\circ} \mathrm{C}$, the intergranular corrosion is still observed but not as clear as on the samples that heated at sensitization temperature. Based on chemical compositions analysis around the grain boundaries, it is found that there are a decreasing content of carbon $(\mathrm{C})$ from $0.61 \%$ mass to $0.47 \%$ mass and that of chrome $(\mathrm{Cr}) 18.37 \%$ mass to17.76\% mass.

Keywords : Intergranular corrosion, Austenitic SS, Heat treatment, Micro structure, SEM-EDS.

\section{PENDAHULUAN}

Penggunaan logam dalam suatu industri memegang peranan sangat penting. Alat dan mesin serta instalasi dalam industri hampir $90 \%$ berasal dari bahan logam, akan tetapi logam memiliki kelemahan yaitu mudah terkorosi sehingga dapat mengakibatkan kegagalan produksi pada komponen industri. Permasalahan korosi menjadi beban bagi peradaban manusia karena kerugian yang dapat menyebabkan terhentinya produksi, disamping karena tingginya biaya perawatan yang dikeluarkan dalam suatu aktivitas industri. Selain itu korosi sangat memboroskan sumber daya alam. Hal ini diketahui dari perhitungan yang telah dilakukan di Inggris bahwa 1 ton baja diubah seluruhnya menjadi karat setiap 90 detik, padahal untuk memproduksi 1 ton baja dari bijih besi diperlukan energi yang besarnya sama dengan kebutuhan energi satu keluarga selama tiga bulan ${ }^{[1]}$.

Salah satu solusi untuk mengurangi terjadinya korosi adalah dengan menggunakan baja tahan karat. Baja tahan karat adalah baja paduan yang memanfaatkan keefektifan unsur paduan Fe-Cr-Ni. Baja tahan karat dengan kadar krom 13\% sampai 27\% akan meningkatkan sifat ketahanan korosi karena keberadaan unsur krom dalam paduan ini akan membentuk krom oksida $\left(\mathrm{Cr}_{2} \mathrm{O}_{3}\right)$ sebagai lapisan pelindung sehingga tidak terbentuk karat. Baja tahan karat austenitik memiliki kandungan $18 \% \mathrm{Cr}$ dan $8 \% \mathrm{Ni}$ dengan ketahanan korosi yang lebih baik, namun mempunyai kelemahan yaitu kerentanannya terhadap korosi antar butir pada temperatur (500-900) ${ }^{0} \mathrm{C}$ yang disebabkan oleh presipitasi krom karbida pada batas butir. Hal ini menyebabkan daerah di dekatnya kekurangan krom sehingga dari daerah 
tersebut korosi dimulai. Fenomena korosi antar butir dapat diamati melalui suatu analisis struktur mikro menggunakan mikroskop optik ${ }^{[2]}$.

Penelitian selingkung tentang ketahanan korosi yang pernah dilakukan antara lain adalah Herlani ${ }^{[3]}$ meneliti efek implantasi elemen reaktif $\mathrm{Y}$ dan $\mathrm{Ce}$ terhadap sifat ketahanan korosi pelat seng dan baja tahan karat SS304, dengan hasil penelitian berupa implantasi ion Y maupun Ce pada pelat seng dan SS304 pada kondisi optimum mempengaruhi laju korosi. Selain itu, Purbowati ${ }^{[4]}$ telah melakukan implantasi ion alumunium pada bahan cor-ten steel untuk peningkatan ketahanan korosi pada temperatur tinggi dengan hasil penelitian menunjukkan adanya lapisan $\mathrm{Al}_{2} \mathrm{O}_{3}$ yang telah terbentuk berfungsi sebagai lapis lindung pada bahan Cor-Ten, sedang dari pengamatan menggunakan alat SEM diperoleh struktur mikro yang tahan terhadap korosi temperatur tinggi menunjukkan adanya butiran yang relatif kecil dan merata. Demikian pula, Aditya ${ }^{[5]}$ telah meneliti pengaruh inhibitor hidrasin terhadap laju korosi baja tahan karat SS304 dalam lingkungan air, $\mathrm{FeU}_{3}$, dan $\mathrm{NiCl}_{2}$ dengan hasil penelitian menunjukkan bahwa inhibitor hidrasin dapat menurunkan laju korosi baja tahan karat SS304 dalam lingkungan korosif (air pendingin sekunder reaktor kartini, $\mathrm{FeU}_{3}$ dan atau $\mathrm{NiCl}_{2}$ ) dengan penambahan konsentrasi yang cukup.

Berdasarkan masalah yang ada, maka dilakukan pengamatan tentang pengaruh temperatur pemanasan terhadap terjadinya korosi antar butir pada material baja tahan karat austenitik, melalui suatu pengamatan struktur mikro. Sedangkan batasan masalah meliputi variasi temperatur pemanasan yang dilakukan terhadap material baja tahan karat austenitik, variasi waktu penahanan (holding time), dan pembuatan gambar struktur mikro material baja tahan karat austenitik untuk variasi temperatur pemanasan yang dilakukan.

Tujuan pengamatan ini adalah mendapatkan struktur mikro material baja tahan karat austenitik yang mengalami korosi antar butir, dan mengetahui pengaruh temperatur pemanasan terhadap terjadinya korosi antar butir pada material baja tahan karat austenitik melalui pengamatan struktur mikro, serta menentukan daerah yang terkena korosi antar butir pada material baja tahan karat austenitik.

Manfaat pengamatan ini antara lain mengetahui tentang struktur mikro korosi antar butir pada material baja tahan karat austenitik, dan mendapatkan informasi mengenai pengaruh temperatur pemanasan terhadap terjadinya korosi antar butir pada material baja tahan karat austenitik melalui pengamatan struktur mikro. 


\section{DASAR TEORI}

\section{Struktur Mikro Baja Tahan Karat Austenitik}

Semua logam terdiri dari partikel-partikel yang disebut kristal atau butirbutir. Struktur kristal suatu logam murni mulai terbentuk sekitar intinya apabila logam mulai membeku dari cairan menjadi padat. Atom-atom bebas dari suatu logam disusun menjadi suatu pola yang beraturan atau latis ruang $^{[6]}$.

Menurut Fontana ${ }^{[7]}$ besi dan baja mempunyai struktur bcc (bodycentered cubic), baja tahan karat austenitik memiliki strukutur fcc (facecentered cubic) dan magnesium berstruktur hcp (hexagonal close-packed). Tiga bentuk kristal logam yang paling umum menurut Scott dan Kanda ${ }^{[8]}$ seperti ditunjukkan pada Gambar 1.

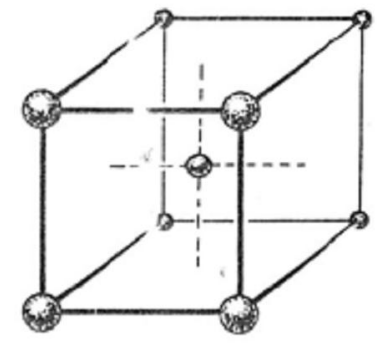

Body-centered cubic

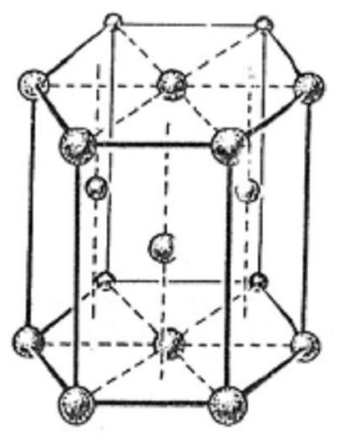

Hexagonal close packed

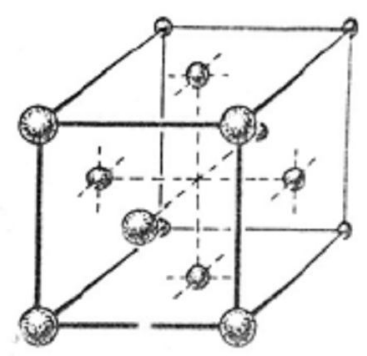

Face.centered cubic

Gambar 1. Struktur Kristal bcc, hcp dan fcc ${ }^{[8]}$

Kalor diekstrasikan dari logam cair, kristal-kristalnya tumbuh ke arah luar dari masing-masing inti (pertumbuhan dendritik) sampai membentuk batasbatas dari butir-butir ${ }^{[6]}$.

Menurut Fontana ${ }^{[7]}$ dan Dieter ${ }^{[9]}$ skema model batas butir ditunjukkan pada Gambar 2. Menurut Surdia dan Saito ${ }^{[2]}$ baja tahan karat austenitik dengan kandungan $18 \% \mathrm{Cr}-8 \% \mathrm{Ni}$ disebut baja tahan karat delapan belas delapan. Baja tahan karat austenitik lebih baik pada ketahanan korosinya, mampu bentuk dan mampu lasnya. 


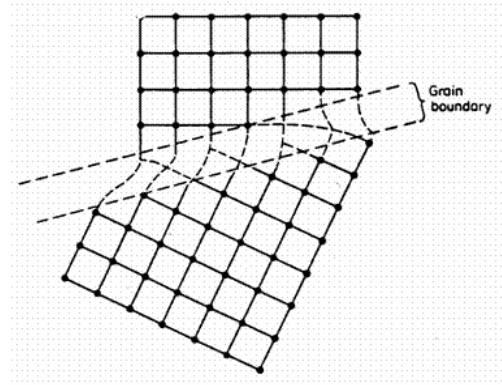

(a)

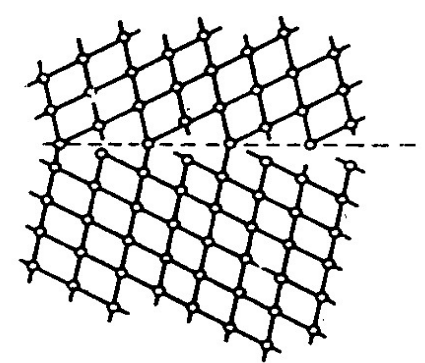

(b)

Gambar 2. Skema Model Batas Butir (a) Menurut Fontana ${ }^{[7]}$

(b) Menurut Dieter ${ }^{[9]}$

\section{Pengertian Korosi Antar Butir.}

Trethewey dan Chamberlain ${ }^{[1]}$ menyatakan bahwa korosi adalah penurunan mutu logam akibat reaksi elektrokimia dengan lingkungannya. Korosi terjadi pada saat adanya reaksi pelarutan (dissolution) logam menjadi ion pada permukaan logam yang berkontak dengan lingkungan yang mengandung cairan/air dan oksigen melalui reaksi kimia. Diawali dengan pelepasan elektron oleh atom-atom logam sehingga atom-atom logam menjadi ion-ion (+) yang larut dalam lingkungannya. Secara umum dapat dirumuskan dalam bentuk persamaan (1).

$$
M \rightarrow M^{Z+}+Z e^{-}
$$

dengan masing-masing menyatakan $\mathrm{M}=$ logam, $\mathrm{M}^{\mathrm{z+}}=$ ion logam, dan $\mathrm{Ze}^{-}=$ muatan negatif elektron. Bilangan bulat $Z$, biasanya mempunyai nilai 1,2 atau 3. Nilai $Z$ yang lebih tinggi juga ada tetapi jarang. Dari nilai $Z$ yang dimungkinkan, 2 merupakan yang paling lazim. Nilai $\mathrm{Z}$ ini disebut valensi, dan logam dapat mempunyai valensi lebih dari satu.

Menurut Fontana ${ }^{[7]}$, korosi diklasifikasikan melalui banyak cara. Ada metode yang membagi korosi menjadi korosi pada temperatur rendah dan temperatur tinggi. Metode lainnya memisahkan korosi menjadi kombinasi langsung (atau oksidasi) dan korosi elektrokimia. Klasifikasi yang lebih disukai adalah korosi basah (wet corrosion) dan korosi kering (dry corrosion). Korosi basah terjadi ketika adanya cairan. Biasanya melibatkan larutan yang mengandung air atau elektrolit dan sejauh ini terhitung menjadi penyebab korosi yang terbesar. Contoh yang paling umum adalah korosi pada baja yang disebabkan oleh air. Korosi kering terjadi ketika tidak adanya fasa cair atau ketika di atas titik embun lingkungan. Pada umumnya uap dan gas 
mengakibatkan terjadinya korosi. Korosi kering paling sering dihubungkan dengan temperatur tinggi. Contohnya korosi baja pada tungku perapian gas.

Delapan bentuk korosi menurut Fontana ${ }^{[7]}$ adalah (1) korosi homogen (uniform corrosion), (2) korosi galvanis (galvanic corrosion), (3) korosi celah (crevice corrosion), (4) korosi sumur (pitting corrosion), (5) korosi antar butir (intergranular corrosion), (6) korosi selektif (selective corrosion), (7) korosi erosi (erotion corrosion), dan (8) korosi tegangan (stress corrosion).

Korosi antar butir ${ }^{[1]}$ terjadi apabila daerah batas butir terserang akibat adanya endapan di dalamnya. Batas butir sering menjadi tempat yang lebih disukai untuk proses-proses pengendapan (precipitation) dan pemisahan (segregation) yang teramati pada banyak paduan. Bahan-bahan asing yang terdapat dalam struktur logam ada 2 macam yaitu logam antara (intermetallic) dan senyawa. Logam antara adalah unsur-unsur yang terbentuk dari atom-atom logam dan mempunyai rumus kimia yang mudah dikenali, contohnya krom karbida $\left(\mathrm{Cr}_{23} \mathrm{C}_{6}\right)$. Unsur ini bisa bersifat anoda atau katoda terhadap logam utama. Senyawa adalah bahan yang terbentuk dari logam dan unsur-unsur bukan logam seperti hidrogen, karbon, silikon, nitrogen maupun oksigen. Setiap logam yang mengandung logam antara atau senyawa pada batas-batas butirnya akan rentan terhadap korosi antar butir (intergranular corrosion) dan yang paling sering adalah dialami oleh baja tahan karat austenitik.

Surdia dan Saito ${ }^{[2]}$ mengatakan bahwa korosi antar butir disebabkan oleh presipitasi karbida $\mathrm{Cr}$ pada batas butir, yang menyebabkan daerah tersebut kekurangan $\mathrm{Cr}$ di dekatnya, dari daerah tersebut korosi dimulai. Dalam keadaan tertentu karbida $\mathrm{Cr}$ sendiri kena korosi. Karbida $\mathrm{Cr}$ berpresipitasi pada daerah temperatur $(500-900){ }^{0} \mathrm{C}$, dan pada $(600-800){ }^{0} \mathrm{C}$ nilai presipitasi paling tinggi.

Bila baja didinginkan perlahan-lahan atau dibiarkan selama beberapa waktu pada $\pm 650^{\circ} \mathrm{C}$, karbon mengendap membentuk karbida krom $\left(\mathrm{Cr}_{23} \mathrm{C}_{6}\right)$ dalam bentuk presipitat halus pada batas butir ${ }^{[10]}$.

Pembentukan kromium karbida yang terkonsentrasi pada batas butir akan menghilangkan/mengurangi sifat perlindungan kromium pada daerah tengah butir, sehingga akan dengan mudah terserang oleh korosi seperti ditunjukkan pada Gambar 3. 


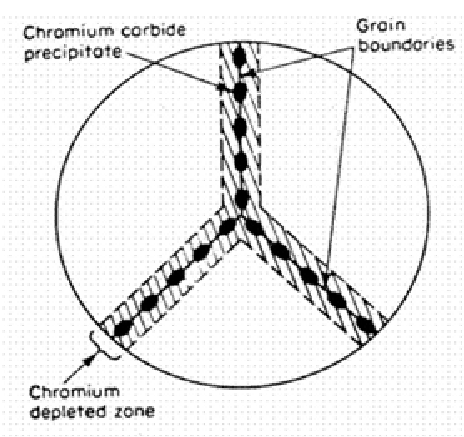

(a)

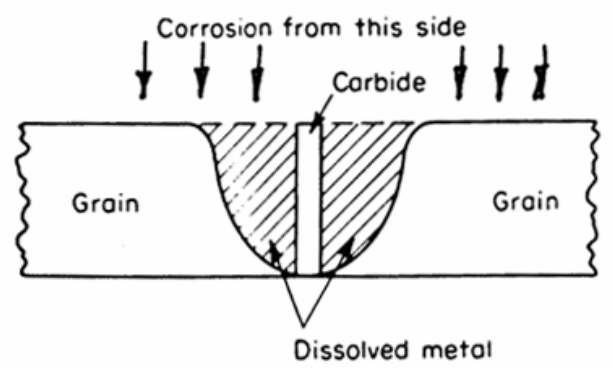

(b)

Gambar 3. Skema Korosi Antar Butir

(a) Batas Butir yang Tersensitisasi (b) Potongan Melintang ${ }^{[7]}$

\section{Perlakuan Panas}

Perlakuan panas adalah suatu proses pemanasan dan pendinginan logam dalam keadaan padat untuk mengubah sifat-sifat fisis logam tersebut. Melalui perlakuan panas yang tepat, tegangan dalam dapat dihilangkan, dan besar butir diperbesar atau diperkecil, serta ketangguhan ditingkatkan atau dapat dihasilkan suatu permukaan yang keras di sekeliling inti yang ulet ${ }^{[11]}$.

\section{Reaksi Oksidasi dan Reduksi}

Dari persamaan (1) maka untuk beberapa logam, reaksi korosi yang terjadi sebagai berikut :

$$
\begin{aligned}
& \mathrm{Fe} \rightarrow \mathrm{Fe}^{2+}+2 \mathrm{e}^{-} \\
& \mathrm{Al} \rightarrow \mathrm{Al}^{3+}+3 \mathrm{e}^{-} \\
& \mathrm{Zn} \rightarrow \mathrm{Zn}^{2+}+2 \mathrm{e}^{-}
\end{aligned}
$$

Apabila lingkungan ikut berperan, maka proses korosi terjadi sebagai akibat reaksi kimia dan elektrokimia.

Korosi sebagai akibat reaksi kimia terjadi apabila misalnya seng ( $\mathrm{Zn}$ ) dimasukkan ke dalam larutan asam chlorida $(\mathrm{HCl})$, maka akan timbul gasgas hidrogen yang menguap melalui reaksi :

$$
\mathrm{Zn}+2 \mathrm{HCl} \rightarrow \mathrm{ZnCl}_{2}+\mathrm{H}_{2} \uparrow \text { (gas, menguap) }
$$

Hal yang sama dapat diamati apabila besi $(\mathrm{Fe})$ dimasukkan ke dalam larutan asam chlorida $(\mathrm{HCl})$ maka reaksi yang terjadi adalah : 


$$
\mathrm{Fe}+2 \mathrm{HCl} \rightarrow \mathrm{FeCl}_{2}+\mathrm{H}_{2} \uparrow \text { (gas, menguap) }
$$

Namun keadaan akan lain bila besi $(\mathrm{Fe})$ dimasukkan ke dalam larutan asam sulfat pekat, ternyata besi tidak terkorosi. Hal ini terjadi karena terbentuknya lapisan besi oksida $\left(\mathrm{Fe}_{2} \mathrm{O}_{3}\right)$ melalui reaksi:

$$
8 \mathrm{Fe}+3 \mathrm{H}_{2} \mathrm{SO}_{4} \rightarrow 4 \mathrm{Fe}_{2} \mathrm{O}_{3}+3 \mathrm{H}_{2} \mathrm{~S} \uparrow \text { (gas, menguap) }
$$

Apabila reaksi kimia tersebut diuraikan lebih jauh, akan terjadi perpindahan elektron sehingga reaksi ini akan terdiri dari reaksi oksidasi dan reduksi (Redoks). Sebagai contoh seng ( $\mathrm{Zn}$ ) yang dimasukkan ke dalam larutan asam chlorida $(\mathrm{HCl})$ :

$$
\mathrm{Zn}+2 \mathrm{HCl} \rightarrow \mathrm{ZnCl}_{2}+\mathrm{H}_{2} \uparrow \text { (gas, menguap) }
$$

Jika ditulis dalam bentuk persamaan :

$$
\mathrm{Zn}+2 \mathrm{H}^{+}+2 \mathrm{Cl}^{-} \rightarrow \mathrm{Zn}^{2+}+2 \mathrm{Cl}^{-}+\mathrm{H}_{2} \uparrow \text { (gas, menguap) }
$$

Persamaan (9) dapat disederhanakan menjadi :

$$
\mathrm{Zn}+2 \mathrm{H}^{+} \rightarrow \mathrm{Zn}^{2+}+\mathrm{H}_{2} \uparrow \text { (gas, menguap) }
$$

Dari persamaan (10) terlihat bahwa valensi logam seng naik dari 0 menjadi 2 disebabkan adanya proses korosi, sedangkan ion hidrogen akan direduksi (valensi turun menjadi gas hidrogen). Untuk reaksi yang lengkap dapat dituliskan sebagai berikut :

$$
\begin{aligned}
& \mathrm{Zn} \rightarrow \mathrm{Zn}^{2+}+2 \mathrm{e}(\text { oksidasi) } \\
& 2 \mathrm{H}^{+}+2 \mathrm{e} \rightarrow \mathrm{H}_{2} \text { (reduksi) } \\
& \mathrm{Zn}+2 \mathrm{H}^{+} \rightarrow \mathrm{Zn}^{2+}+\mathrm{H}_{2}
\end{aligned}
$$

Dalam proses korosi, reaksi oksidasi disebut reaksi anodik sedangkan reaksi reduksi disebut reaksi katodik. Secara umum reaksi anodik sering dinamakan reaksi logam sehingga persamaannya sama dengan Persamaan (1). Sedangkan reaksi katodik yang mungkin terjadi selama proses korosi adalah

Pelepasan hidrogen :

$$
2 \mathrm{H}^{+}+2 \mathrm{e} \rightarrow \mathrm{H}_{2} \uparrow
$$


Reduksi oksigen (lingkungan asam): $\quad \mathrm{O}_{2}+4 \mathrm{H}^{+}+4 \mathrm{e} \rightarrow 2 \mathrm{H}_{2} \mathrm{O}$

Reduksi oksigen (lingkungan netral/basa): $\mathrm{O}_{2}+4 \mathrm{H}_{2} \mathrm{O}+4 \mathrm{e} \rightarrow 2 \mathrm{H}_{2} \mathrm{O}$

Reduksi ion logam: $\quad \mathrm{Fe}^{3+}+\mathrm{e} \rightarrow \mathrm{Fe}^{2+}$

\section{Peristiwa Sensitisasi}

Kecenderungan suatu bahan untuk terkorosi sangat ditentukan oleh jenis maupun sifat-sifat bahan maupun lingkungannya. Sifat-sifat bahan sangat ditentukan oleh beberapa faktor di antaranya adalah jenis unsur paduan, cara perlakuan pemanasan maupun cacat-cacat yang menyertai saat pengerjaan. Peristiwa sentisisasi dapat mengakibatkan terjadinya korosi antar butir. Hal ini disebabkan ketidaksempurnaan struktur mikro baja tahan karat ketika berada pada temperatur sensitisasi (500-900) ${ }^{0} \mathrm{C}$ dan dibiarkan mendingin secara perlahan maka atom karbon akan menarik atom-atom krom untuk membentuk partikel kromium karbida (chromium carbide) di daerah batas butir (grain boundary) seperti ditunjukkan Gambar $4^{[12]}$.

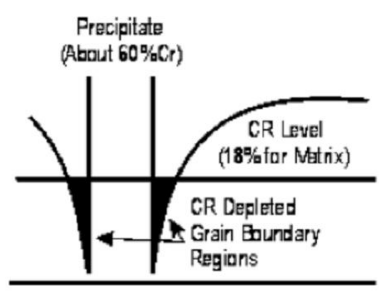

(a)

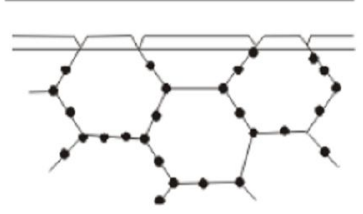

(b)

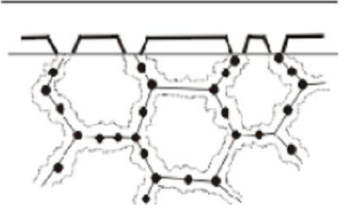

(c)

Gambar 4. Skema Korosi Antar Butir pada Baja Tahan Karat Austenitik ${ }^{[12]}$

Pada Gambar 4(a) menunjukkan daerah yang kekurangan krom (Cr) di sekitar batas butir, Gambar 4(b) menunjukkan endapan krom karbida $\left(\mathrm{Cr}_{23} \mathrm{C}_{6}\right)$ pada batas butir, Gambar 4(c) menunjukkan daerah yang terkena korosi antar butir.

\section{Unsur Paduan Baja Tahan Karat Austenitik}

Diagram fasa Fe-C menunjukkan hubungan antara jenis struktur baja berkaitan dengan kandungan karbon dan temperatur pemanasannya seperti ditunjukkan pada Gambar 5. Dari diagram fasa tersebut terlihat bahwa austenit $(\gamma-\mathrm{Fe})$ yang strukturnya berbentuk fcc, terdiri atas $0,028 \%$ massa karbon (C) pada temperatur $738{ }^{\circ} \mathrm{C}$ dan jika temperatur mencapai $1154{ }^{\circ} \mathrm{C}$ maka kandungan karbonnya 2,08\%. 


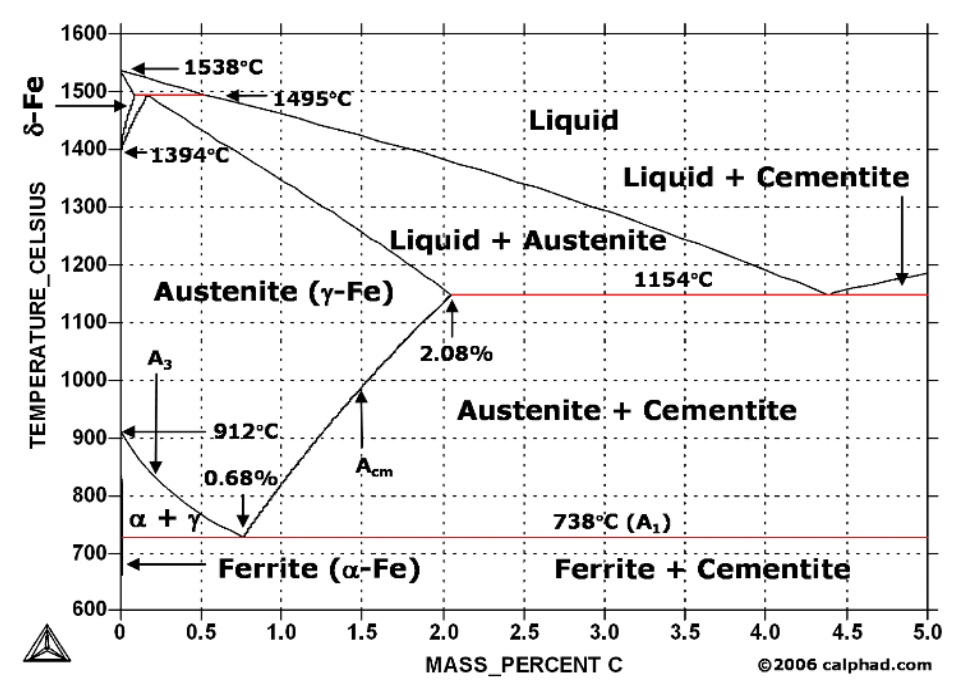

Gambar 5. Diagram Fasa Fe-C ${ }^{[13]}$

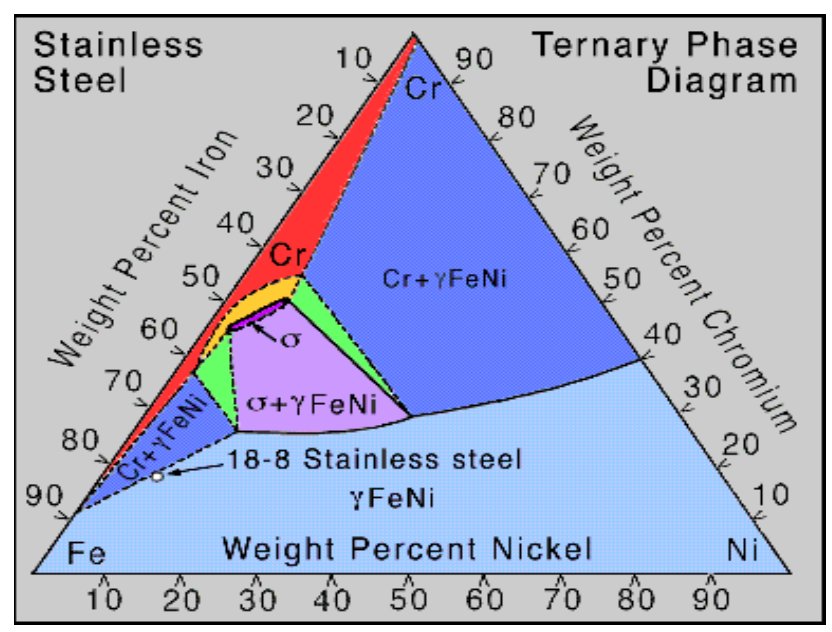

Gambar 6. Diagram Fasa Fe-Ni-Cr pada Temperatur $900^{\circ} \mathrm{C}^{[14]}$

Baja tahan karat adalah baja paduan yang memanfaatkan keefektifan unsur Fe-Cr-Ni seperti yang diperlihatkan pada Gambar $6^{[14]}$. Baja tahan karat Austenitik dengan komposisi 17-25 \% Cr, 8-20 \% Ni dan 0,08-0,1 \% C juga terdapat unsur tambahan lain seperti Ti, Mo, Cu, Nb dan Al. Pada baja tahan karat austenitik yang menjadi paduan utama adalah $\mathrm{Cr}$, sebagai peran utama dalam menaikkan ketahanan korosi baja tahan karat.

Di samping unsur krom terdapat juga unsur-unsur lain sebagai paduan. Masing-masing unsur mempunyai fungsi tertentu. Pada Tabel 1 ditunjukkan beberapa pengaruh unsur paduan di dalam baja tahan karat. 
Tabel 1. Pengaruh Unsur Paduan Baja Tahan Karat Austeniti ${ }^{[12]}$

\begin{tabular}{|c|c|c|}
\hline No & UNSUR & PENGARUH \\
\hline \multirow[t]{2}{*}{1} & Karbon (C) & Menaikkan kekerasan \\
\hline & & Pembentuk karbida krom menurunkan ketahanan korosi. \\
\hline \multirow[t]{2}{*}{2} & $\operatorname{Krom}(\mathrm{Cr})$ & Pembentuk ferrit \\
\hline & & Menaikkan ketahanan korosi \\
\hline \multirow[t]{2}{*}{3} & Nikel (Ni) & Pembentukan austenit \\
\hline & & $\begin{array}{l}\text { Menaikkan kekuatan pada temperatur tinggi. } \\
\text { Menaikkan ketahanan korosi }\end{array}$ \\
\hline 4 & Nitrogen $(\mathrm{N})$ & $\begin{array}{l}\text { Pembentuk austenit yang sangat kuat, yaitu (26-30) kali dari } \\
\text { pengaruh } \mathrm{Ni}\end{array}$ \\
\hline 5 & Niobium $(\mathrm{Nb})$ & $\begin{array}{l}\text { Unsur pembentuk karbida yang kuat, sehingga menghindari } \\
\text { terjadinya karbida Cr. } \\
\text { Pembentuk ferrit }\end{array}$ \\
\hline \multirow{2}{*}{6} & Mangan $(\mathrm{Mn})$ & Pembentuk ferrit nada temneratur tinooi \\
\hline & & Menstabilkan austenit pada temperatur tinggi \\
\hline 7 & Molybdenum (Mo) & $\begin{array}{l}\text { Menaikkan kekuatan pada temperatur tinggi } \\
\text { Pembentuk ferrit. }\end{array}$ \\
\hline 8 & Titanium (Ti) & $\begin{array}{l}\text { Unsur pembentuk karbida yang kuat, sehingga menghindari } \\
\text { terjadinya karbida Cr. } \\
\text { Pembentuk ferrit. } \\
\text { Menaikkan mampu mesin }\end{array}$ \\
\hline 9 & Phospor (P) & Sedikit menurunkan ketahanan korosi. \\
\hline 10 & Sulfur $(S)$ & $\begin{array}{l}\text { Menaikkan kegetasan, hanya diperkenankan kadar S antara } \\
(0,025-0,030) \%\end{array}$ \\
\hline
\end{tabular}

Hubungan berbagai jenis baja tahan karat (stainless steel) ditunjukkan pada Gambar 7.

\section{Sifat Baja Tahan Karat Austenitik}

Baja tahan karat austenitik mempunyai struktur kristal fcc. Baja tahan karat austenitik tidak dapat dikeraskan dengan cara perlakuan panas tetapi dikeraskan dengan cara pengerjaan dingin (cold working). Baja tahan karat austenitik mempunyai beberapa kelebihan di antaranya : bersifat non magnetik, mampu bentuk baik, ketahanan korosi tinggi, serta memiliki sifat keuletan dan ketangguhan yang sangat baik.

Berdasarkan tinjauan pustaka dan landasan teori dapat dihipotesiskan bahwa pada temperatur sensitisasi, struktur mikro material baja tahan karat austenitik akan menunjukkan adanya endapan krom karbida $\left(\mathrm{Cr}_{23} \mathrm{C}_{6}\right)$ pada batas butir, yang mengakibatkan daerah di sekitar batas butir akan kekurangan krom $(\mathrm{Cr})$ bebas sehingga akan mudah terserang korosi karena tidak terbentuknya lapisan pelindung krom oksida $\left(\mathrm{Cr}_{2} \mathrm{O}_{3}\right)$. 


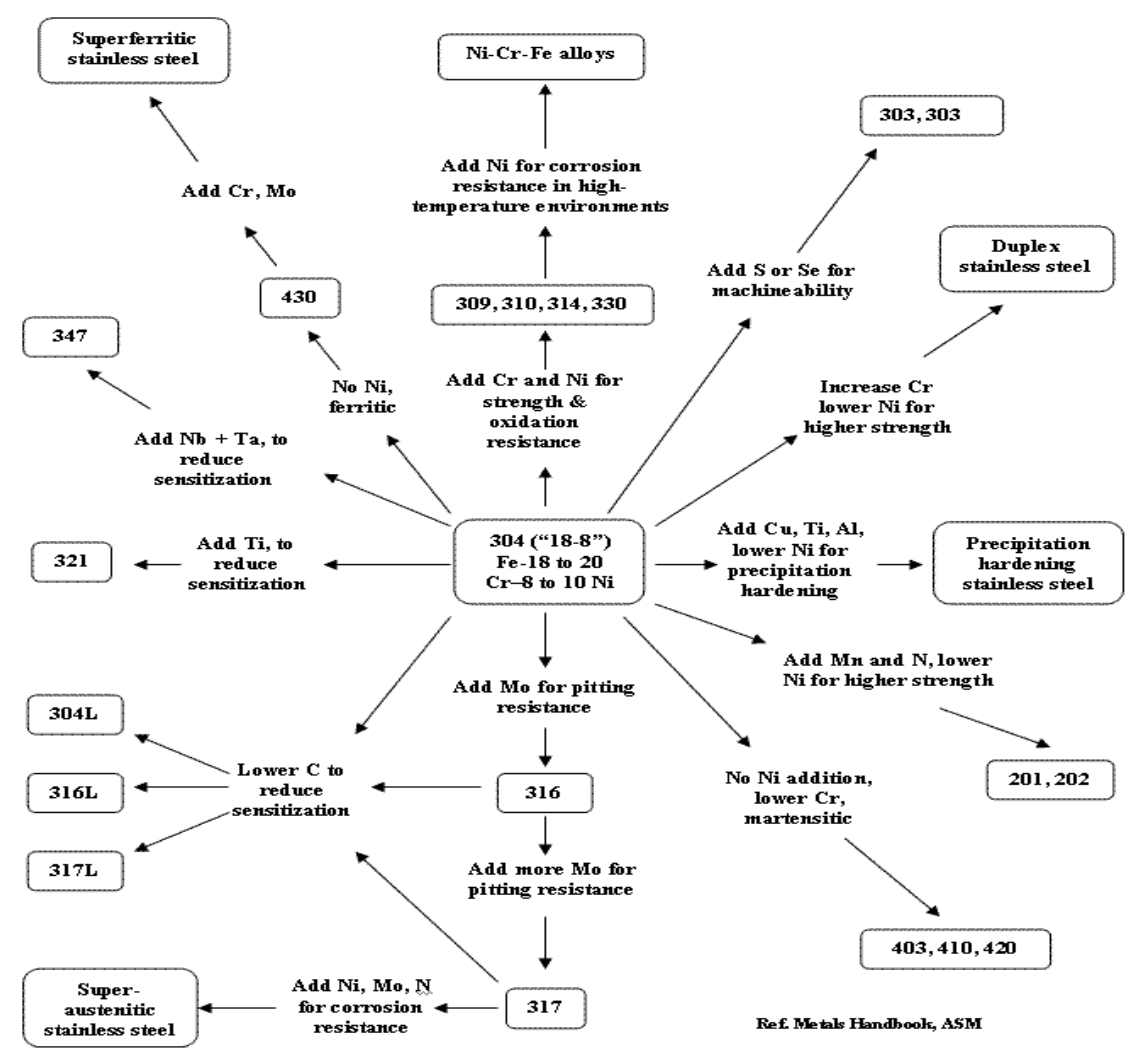

Gambar 7. Diagram Hubungan Berbagai Jenis Baja Tahan Karat (Stainless Steel) $^{[12]}$

\section{METODE PENELITIAN}

Alat

Alat yang digunakan dalam penelitian ini adalah alat poles, gunting, oven (furnace), mikroskop optik, dan SEM (Scanning Electron Microscope).

\section{Bahan}

Bahan yang digunakan adalah baja tahan karat SS304, kain bludru, autosol, larutan $\mathrm{HCl}$, larutan $\mathrm{HNO}_{3}$, dan kertas abrasive.

\section{Prosedur Kerja Penelitian}

Prosedur kerja penelitian yang dilakukan ditunjukkan pada Gambar 8, mencakup preparasi sampel, perlakuan panas, pendinginan alami (normalising), pemolesan (polishing), pengetsaan (etching), dan pegamatan struktur mikro. 


\section{Preparasi Sampel}

Sampel bahan SS 304 yang berbentuk batangan dan memiliki diameter 18 $\mathrm{mm}$, dipotong menggunakan mesin bubut dengan ketebalan $6 \mathrm{~mm}$. Ini disebabkan karena kemampuan mesin bubut untuk memotong dengan ketebalan di bawah $6 \mathrm{~mm}$ mengalami kesulitan.

Untuk keperluan pengambilan data dengan variasi perlakuan panas dan waktu penahanan diberikan pada Tabel 2, maka banyaknya sampel yang dibuat adalah 10 sampel, Contoh sampel yang digunakan seperti pada Gambar 9.

\section{Perlakuan Panas}

Proses selanjutnya adalah perlakuan panas yang dilakukan dengan cara sampel dimasukkan ke dalam oven dan dilakukan pemanasan dengan variasi temperatur dan variasi waktu penahanan. Dengan perlakuan panas dapat diubah sifat-sifat fisis logam tersebut. Melalui perlakuan panas yang tepat, tegangan dalam dapat dihilangkan, besar butir diperbesar atau diperkecil, ketangguhan ditingkatkan atau dapat dihasilkan suatu permukaan yang keras di sekeliling inti yang ulet ${ }^{[11]}$. Oven yang digunakan seperti pada Gambar 10.

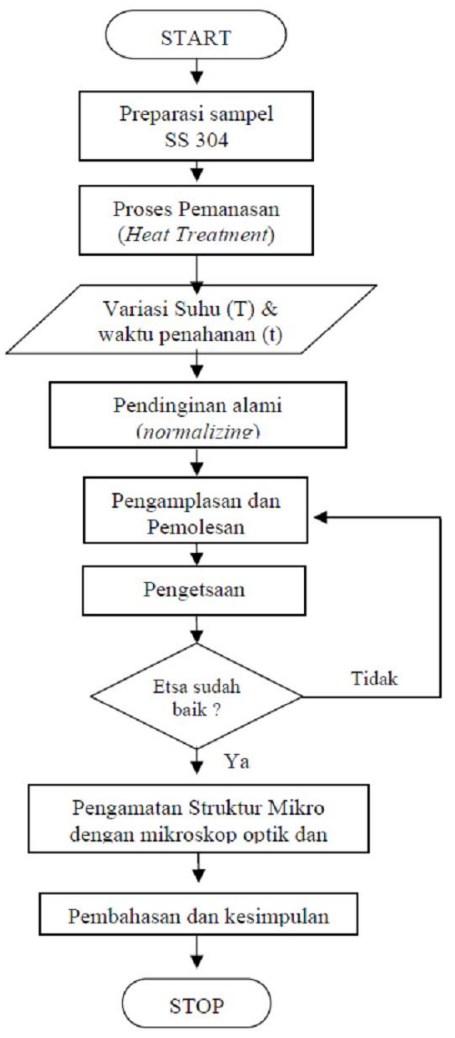

Gambar 8. Diagram Alir Penelitian 


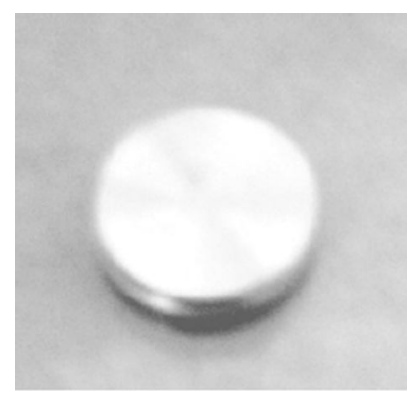

Gambar 9. Contoh Sampel

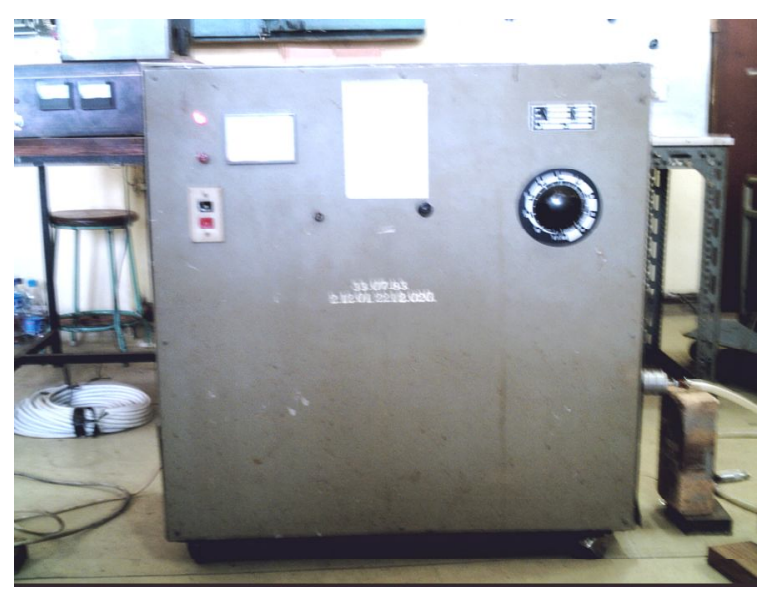

Gambar 10. Oven

Waktu penahanan, dilakukan dengan cara memantau suhu oven secara terus menerus dan melakukan penyesuaian setting pemanasan berulang kali agar temperatur konstan pada suhu yang diinginkan sesuai dengan Tabel 2.

\section{Pendinginan Alami}

Sampel yang telah mengalami proses perlakuan panas kemudian didinginkan secara alami dalam media udara. Dengan pendinginan alami dalam media udara, turunnya suhu secara perlahan-lahan menyebabkan karbon akan membentuk karbida khrom dalam bentuk presipitat halus pada batas butir ${ }^{[10]}$. Contoh sampel seperti pada Gambar 11.

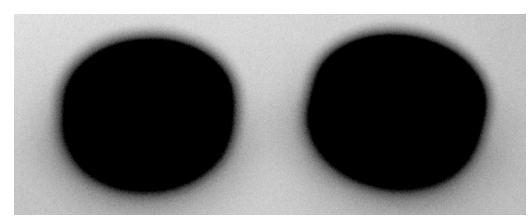

Gambar 11. Sampel yang Telah Didinginkan 
Tabel 2. Setting Waktu Pemanasan

\begin{tabular}{cccc}
\hline Waktu & Suhu $\left({ }^{\circ} \mathrm{C}\right)$ & Suhu $\left({ }^{\circ} \mathrm{C}\right)$ & Suhu $\left({ }^{\circ} \mathrm{C}\right)$ \\
\cline { 2 - 4 } & $(1)$ & $(2)$ & $(3)$ \\
\hline 6.30 & 0 & 0 & 0 \\
8.00 & 400 & 600 & 600 \\
8.30 & 450 & 650 & 700 \\
9.00 & 550 & 725 & 750 \\
9.30 & 625 & 775 & 800 \\
10.00 & 675 & 800 & 850 \\
10.30 & 720 & 825 & 900 \\
11.00 & 750 & 850 & 900 \\
11.30 & 775 & 850 & 900 \\
12.00 & - & 850 & 900 \\
12.30 & - & 850 & 900 \\
13.00 & - & 850 & 925 \\
13.30 & - & 860 & 925 \\
14.00 & - & 860 & 925 \\
14.30 & - & 850 & 900 \\
15.00 & - & 850 & 900 \\
\hline
\end{tabular}

\section{Pemolesan}

Proses pemolesan dilakukan dengan cara :

a. Pemolesan terhadap sampel dilakukan menggunakan alat polishing yang telah dipasang kertas abrasive. Pemolesan dilakukan secara bertahap dimulai dengan menggunakan kertas abrasive yang berukuran 240 mesh, 360 mesh, 600 mesh, 800 mesh, dan terakhir 1000 mesh. Selama dilakukan pemolesan perlu disemprotkan air untuk menghilangkan partikel abrasif dan untuk mengurangi panas yang timbul akibat pemolesan sehingga tidak terjadi perubahan struktur mikro dari sampel. Alat polishing yang digunakan seperti pada Gambar 12.

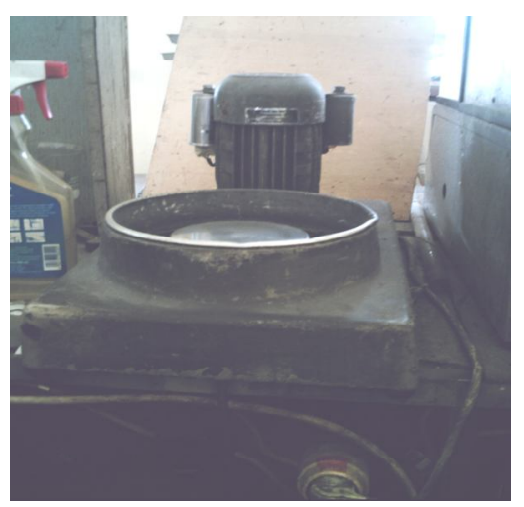

Gambar 12. Alat Polis

Selanjutnya dilakukan pemolesan dengan alat polishing yang telah dipasang kain bludru. Pada tahap ini tidak lagi disemprotkan air, tetapi digunakan 
autosol agar hasil pemolesan lebih maksimal. Pemolesan dilakukan untuk mendapatkan permukaan sampel yang halus dan mengkilat seperti kaca tanpa gores. Dengan memperoleh permukaan sampel yang halus tanpa goresan dan mengkilap seperti cermin maka akan menghilangkan ketidakteraturan sampel hingga orde $0,01 \mu \mathrm{m}$.

\section{Pengetsaan}

Sampel dietsa menggunakan larutan etsa aqua regia yang terdiri dari larutan $\mathrm{HNO}_{3}$ 2,5\% dan larutan $\mathrm{HCl}$, dengan perbandingan 1:3. Setelah logam dipolis, permukaan logam yang halus dan tertutup oleh selaput terdeformasi, Sehingga dengan pengetsaan selaput tersebut terkikis dan permukaan menjadi buram, sebagian batas butir terkikis dan komponen-komponen tertentu akan nampak akibat kikisan selektif dari larutan etsa tadi ${ }^{[1]}$. Hasil etsa seperti ditunjukkan dalam Gambar 13.

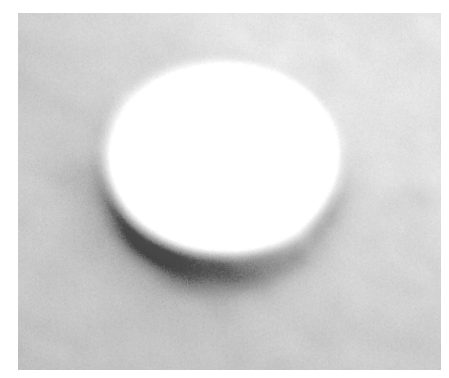

Gambar 13. Sampel yang Telah di Etsa

\section{Pengamatan Struktur Mikro}

Untuk mengetahui fenomena terjadinya korosi antar butir, maka dilakukan pengamatan dengan menggunakan mikroskop optik. Pembuatan foto struktur mikro dari sampel dilakukan menggunakan mikroskop optik seperti ditunjukkan pada Gambar 14.

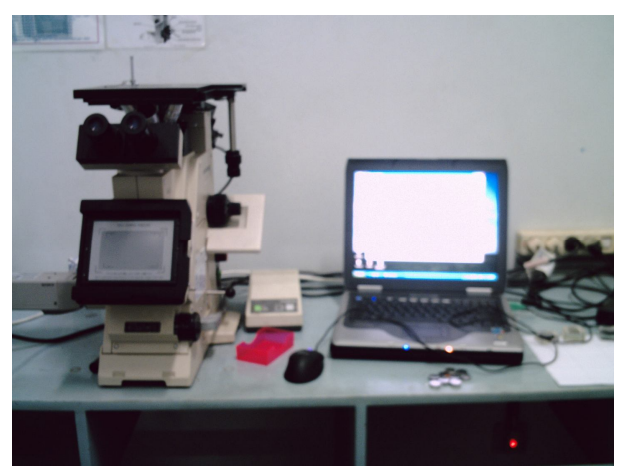

Gambar 14. Mikroskop Optik 


\section{HASIL PENELITIAN DAN PEMBAHASAN}

Hasil penelitian dan pembahasan terdiri atas data variasi suhu dan waktu penahanan, dan data komposisi kimia, serta struktur mikro sampel SS 304.

\section{Variasi Perlakuan Panas dan Waktu Penahanan}

Dari penelitian yang dilakukan maka diperoleh data dari beberapa sampel yang telah mengalami proses pemanasan dengan variasi suhu pemanasan dan waktu penahanan seperti dalam Tabel 3.

Tabel 3. Data Variasi Perlakuan Panas dan Waktu Penahanan

\begin{tabular}{cc}
\hline Suhu & Waktu penahanan \\
\hline $900^{\circ} \mathrm{C}$ & $3 \mathrm{jam}$ \\
$900^{\circ} \mathrm{C}$ & $31 / 2 \mathrm{jam}$ \\
$900^{\circ} \mathrm{C}$ & $1 \mathrm{jam}$ \\
$900^{\circ} \mathrm{C}$ & $4 \mathrm{jam}$ \\
$950^{\circ} \mathrm{C}$ & $3 \mathrm{jam}$ \\
$650^{\circ} \mathrm{C}$ & $3 \mathrm{jam}$ \\
$400^{\circ} \mathrm{C}$ & $2 \mathrm{jam}$ \\
\hline
\end{tabular}

\section{Komposisi Kimia Sampel SS 304}

Dari pengujian menggunakan SEM-EDS (Scanning Electron MicroscopeEnergy Dispersive $X$-ray Spectrometer) maka dapat dianalisis komposisi kimia daerah batas butir dengan hasil sebagai berikut :

a. Sampel yang mengalami perlakuan panas pada suhu $900^{\circ} \mathrm{C}$ dengan waktu penahanan 3 jam ditunjukkan pada Gambar 15.

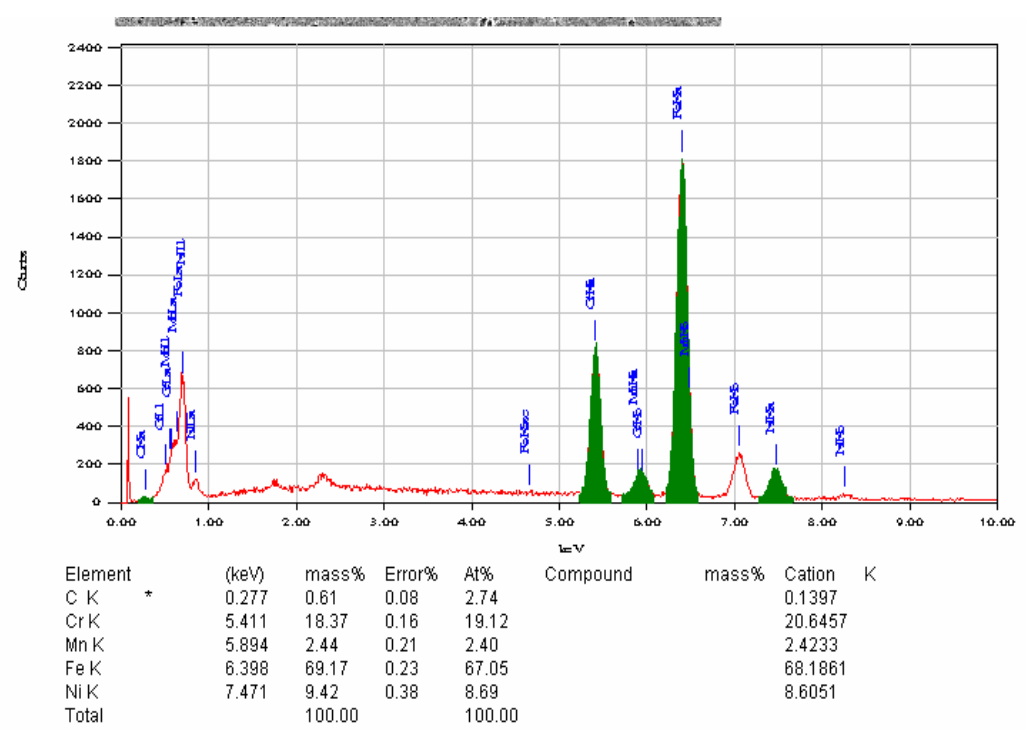

Gambar 15. Komposisi Kimia Sampel SS 304 Suhu $900^{\circ} \mathrm{C}$ Holding Time 3 Jam 
b. Sampel yang mengalami perlakuan panas pada suhu $900^{\circ} \mathrm{C}$ dengan waktu penahanan 31/2 jam ditunjukkan pada Gambar 16.

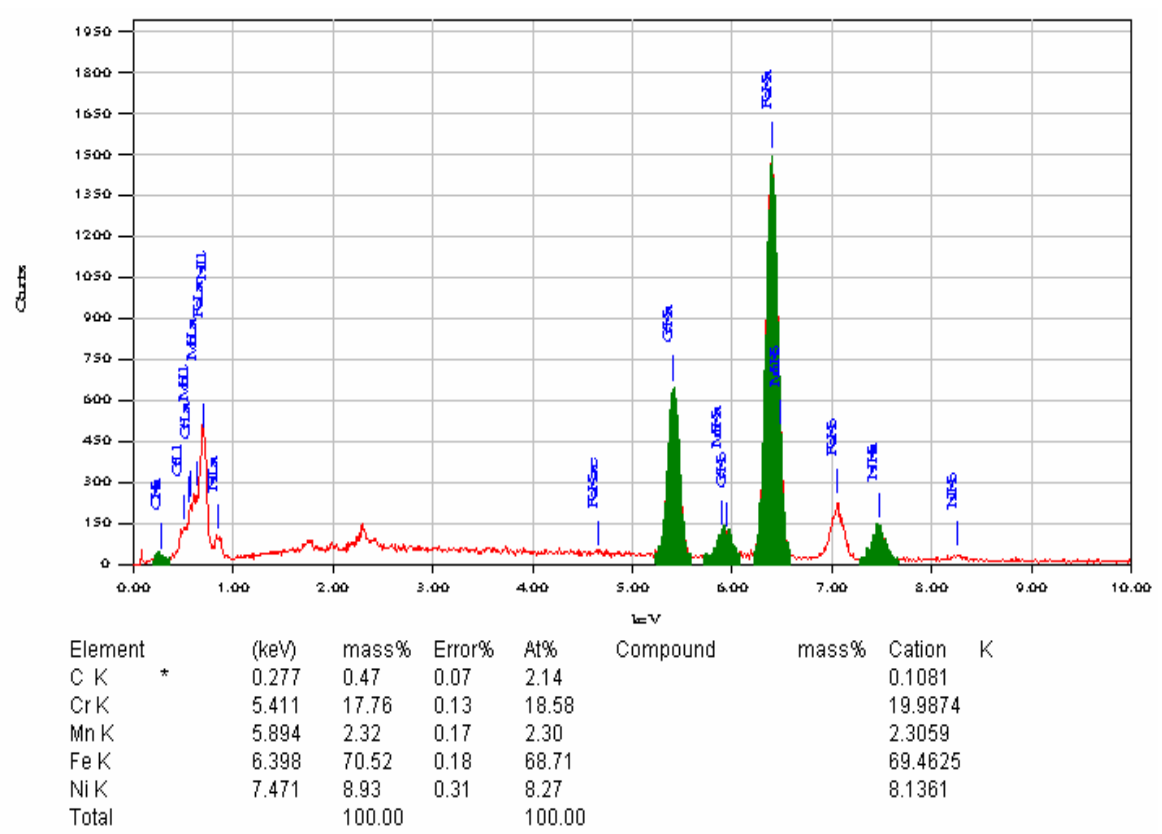

Gambar 16. Komposisi Kimia Sampel SS 304 Suhu $900^{\circ} \mathrm{C}$ Holding Time 31니 Jam

Dari Gambar 15 dan Gambar 16 dapat diketahui hasil pengujian EDS (Energy Dispersive X-ray Spectrometer) untuk sampel SS 304 suhu $900^{\circ} \mathrm{C}$ waktu penahanan 3 jam dan 31/2 jam yang diambil pada daerah di sekitar batas butir. Dari hasil tersebut jika dibandingkan antara sampel mengalami perlakuan panas pada suhu $900^{\circ} \mathrm{C}$ dengan waktu penahanan 3 jam dengan sampel yang mengalami perlakuan panas pada suhu $900^{\circ} \mathrm{C}$ dengan waktu penahanan $3 \frac{1}{2}$ jam maka terjadi penurunan nilai komposisi unsur karbon (C) dan krom $(\mathrm{Cr})$. Kandungan karbon $(\mathrm{C})$ dari $0,61 \%$ massa menjadi $0,47 \%$ massa dan untuk khrom (Cr) $18,37 \%$ massa menjadi $17,76 \%$. Hal ini menunjukkan bahwa di sekitar batas butir kekurangan krom bebas karena atom karbon mengendap membentuk karbida khrom dalam bentuk presipitat halus pada batas butir, sehingga menyebabkan tidak terbentuknya lapis pelindung terhadap korosi yaitu krom oksida $\left(\mathrm{Cr}_{2} \mathrm{O}_{3}\right)$ sehingga bersifat sangat anodik dan jika logam bertemu dengan elektrolit akan terjadi korosi antar butir (intergranular corrosion). 


\section{Data Gambar Struktur Mikro}

Pembuatan gambar struktur mikro dilakukan dengan menggunakan mikroskop optik dan SEM. Untuk gambar struktur mikro sampel yang menggunakan mikroskop optik dengan perbesaran 1 strip sama dengan 10 mikron, diperoleh data sebagaimana pada Gambar 17.

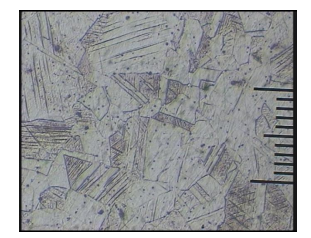

a. Tanpa perlakuan panas.

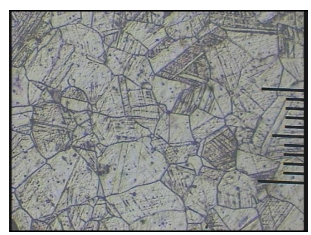

c. Suhu $650^{\circ} \mathrm{C}$, waktu penahanan $3 \mathrm{jam}$.

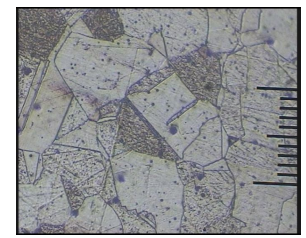

e. Suhu $900^{\circ} \mathrm{C}$, waktu penahanan 3 jam.

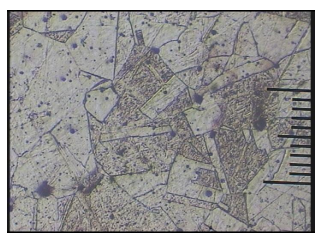

g. Suhu $900^{\circ} \mathrm{C}$, waktu penahanan 4 jam. b. Suhu $400^{\circ} \mathrm{C}$, waktu penahanan 2 jam.

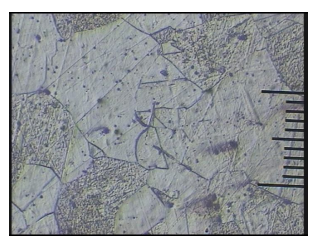

d. Suhu $900^{\circ} \mathrm{C}$, waktu penahanan 1 jam.

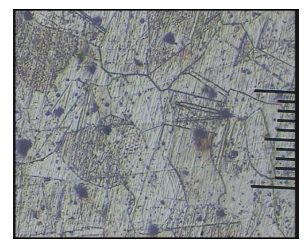

f. Suhu $900^{\circ} \mathrm{C}$, waktu penahanan $3 \frac{1}{2}$ jam.

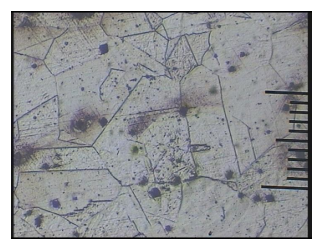

h. Suhu $950^{\circ} \mathrm{C}$, waktu penahanan 3 jam.

\section{Gambar 17. Struktur Mikro Sampel yang Menggunakan Mikroskop Optik \\ dengan Perbesaran 1 Strip Sama dengan 10 Mikron.
dentros}


Sedangkan untuk gambar struktur mikro sampel yang menggunakan SEM diperoleh data gambar struktur mikro sampel yang tidak mengalami perlakuan panas ditunjukkan pada Gambar 18(a). Dan untuk gambar struktur mikro sampel yang mengalami perlakuan panas pada suhu $900^{\circ} \mathrm{C}$ dengan waktu penahanan 31/2 jam ditunjukkan pada Gambar 18(b).

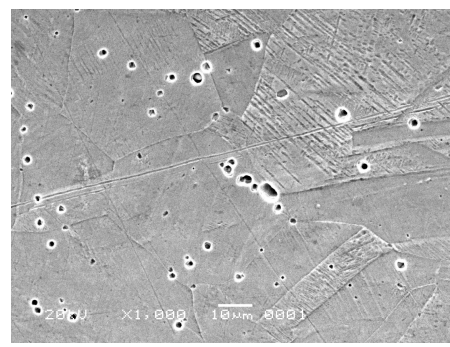

(a) Tanpa Perlakuan panas (dengan SEM)

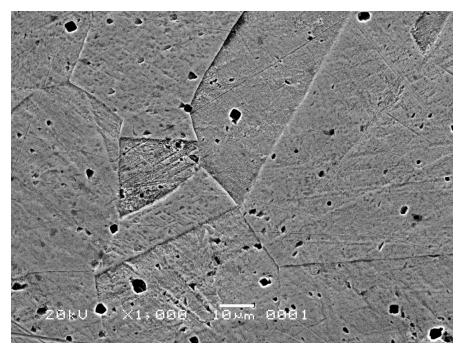

(b) Suhu $900^{\circ} \mathrm{C}$ dengan waktu penahanan 31/2 jam (dengan SEM)

Gambar 18. Struktur Mikro Sampel Menggunakan SEM yang Mengalami

Waktu Penahanan pada Suhu $900^{\circ} \mathrm{c}$ dengan Waktu Penahanan 31리 Jam

Dari hasil pengamatan gambar struktur mikro maka dapat diketahui fenomena yang terjadi untuk perlakuan panas di bawah temperatur sensitisasi $\left(400^{\circ} \mathrm{C}\right)$, pada temperatur sensitisasi $\left(500^{\circ} \mathrm{C}\right.$ s $\left./ \mathrm{d} 900^{\circ} \mathrm{C}\right)$, dan di atas temperatur sensitisasi $\left(950^{\circ} \mathrm{C}\right)$.

Di Bawah Temperatur Sensitisasi $\left(400^{\circ} \mathrm{c}\right)$

Dari gambar struktur mikro dengan menggunakan mikroskop optik maka diketahui bahwa di bawah temperatur sensitisasi, korosi antar butir tidak teramati, hal ini dibuktikan dari sampel yang telah mengalami perlakuan panas pada suhu $400^{\circ} \mathrm{C}$ tidak terlihat adanya daerah tebal pada batas butir yang merupakan indikasi terjadinya korosi antar butir seperti pada Gambar 19(a).

Pada Temperatur Sensitisasi $\left(500^{\circ} \mathrm{C} \mathrm{s} / \mathrm{d} 900^{\circ} \mathrm{C}\right)$

Untuk sampel yang mengalami perlakuan panas pada rentang suhu $500^{\circ} \mathrm{C}-$ $900^{\circ} \mathrm{C}$ akan terlihat batas butir yang tebal sebagai indikasi terjadinya korosi antar butir dengan perbandingan sebagai berikut :

a. Untuk sampel yang mengalami perlakuan panas dengan suhu yang lebih tinggi maka ada beberapa bagian pada batas butir yang terlihat lebih tebal yang menunjukkan daerah yang terkorosi jika dibandingkan dengan sampel yang mengalami perlakuan panas dengan suhu lebih rendah. Hal ini terlihat dengan jelas ketika gambar struktur mikro dari sampel yang mengalami perlakuan panas dengan suhu $650^{\circ} \mathrm{C}$ waktu penahanan 3 jam 
dibandingkan dengan gambar struktur mikro dari sampel yang mengalami perlakuan panas dengan suhu $900^{\circ} \mathrm{C}$ waktu penahanan 3 jam seperti pada Gambar 19 (c)-(h). Beberapa bagian pada batas butir yang terlihat lebih tebal mengindikasikan terjadinya korosi antar butir lebih banyak.

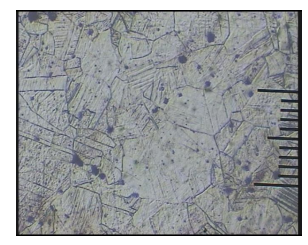

(a) Suhu $400^{\circ} \mathrm{C}$ Waktu Penahanan 2 Jam

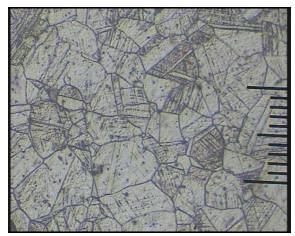

(c) Suhu $650^{\circ} \mathrm{C}$ Waktu Penahanan $3 \mathrm{Jam}$

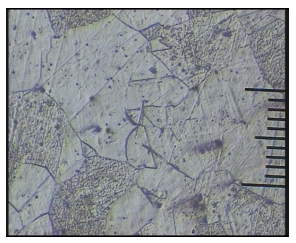

(e) Suhu $900^{\circ} \mathrm{C}$ Waktu Penahanan $1 \mathrm{Jam}$

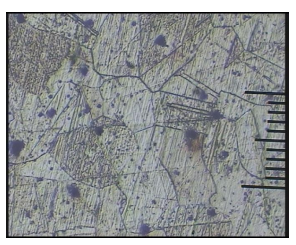

(g) Suhu $900^{\circ} \mathrm{C}$ Waktu Penahanan $31 / 2$ Jam

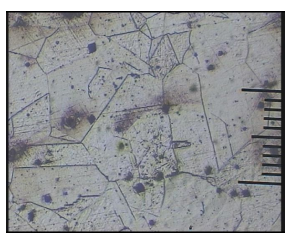

(b) Suhu $950^{\circ} \mathrm{C}$ Waktu Penahanan $3 \mathrm{Jam}$

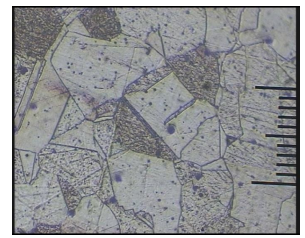

(d) Suhu $900^{\circ} \mathrm{C}$ Waktu Penahanan $3 \mathrm{Jam}$

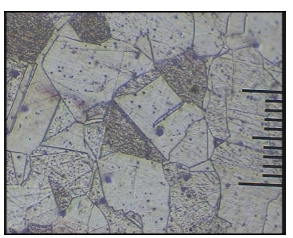

(f) Suhu $900^{\circ} \mathrm{C}$ Waktu Penahanan $3 \mathrm{Jam}$

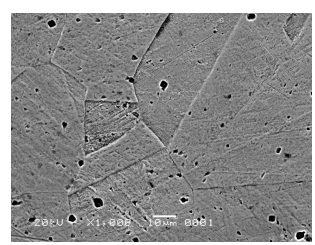

(h) Suhu $900^{\circ} \mathrm{C}$ Waktu Penahanan 31/2 Jam (dengan SEM)

Gambar 19. Kondisi Sampel pada Suhu (600-900) ${ }^{\circ} \mathrm{C}$ dengan Variasi Waktu Penahanan. 
b. Untuk sampel yang mengalami perlakuan panas pada suhu yang sama namun waktu penahanan berbeda, akan terlihat bahwa sampel dengan waktu penahanan yang lebih lama menunjukkan adanya beberapa bagian pada batas butir yang terlihat lebih tebal sebagai indikasi terjadinya korosi antar butir yang lebih banyak. Karbon akan mengendap bila pendinginan kurang cepat sehingga endapan krom karbida yang terbentuk akan lebih banyak yang menyebabkan daerah disekitar batas butir akan kekurangan krom bebas. Hal ini menyebabkan tidak terbentuknya lapis pelindung terhadap korosi yaitu krom oksida $\left(\mathrm{Cr}_{2} \mathrm{O}_{3}\right)$ sehingga di sekitar batas butir akan terjadi korosi antar butir, seperti ditunjukkan pada Gambar 19.

Di Atas Temperatur Sensitisasi $\left(950^{\circ} \mathrm{C}\right)$

Dari pengamatan gambar struktur mikro sampel yang mengalami perlakuan panas di atas temperatur sensitisasi yaitu pada suhu $950^{\circ} \mathrm{C}$, korosi antar butir masih teramati tetapi tidak sejelas sampel yang mengalami perlakuan panas pada temperatur sensitisasi $\left(500^{\circ} \mathrm{C}\right.$ s/d $\left.900^{\circ} \mathrm{C}\right)$ seperti ditunjukkan Gambar 19(b).

Pada umumnya peristiwa sensitisasi terjadi dalam rentang suhu $500^{\circ} \mathrm{C}$ s/d $900^{\circ} \mathrm{C}$. Namun didalam penelitian ini pada suhu $950^{\circ}$ masih ada batas butir yang terlihat tebal sebagai indikasi terjadinya korosi antar butir walaupun hanya sedikit disebabkan karena temperatur yang mengakibatkan peristiwa sensitisasi untuk setiap material berbeda hal ini tergantung beberapa hal salah satunya dari komposisi material baja tahan karat yang mengalami proses perlakuan panas.

\section{KESIMPULAN}

Dari penelitian ini dapat diambil kesimpulan sebagai berikut :

1. Dari pengamatan gambar struktur mikro menggunakan mikroskop optik dan SEM diketahui bahwa sampel yang mengalami perlakuan panas di bawah temperatur sensitisasi yaitu pada suhu $400^{\circ} \mathrm{C}$, ternyata korosi antar butir tidak teramati.

2. Dari pengamatan gambar strukutr mikro menggunakan mikroskop optik dan SEM diketahui bahwa sampel yang mengalami perlakuan panas pada temperatur sensitisasi yaitu pada suhu $500^{\circ} \mathrm{C}$ s $/ \mathrm{d} 900^{\circ} \mathrm{C}$, ternyata korosi antar butir teramati dengan jelas.

3. Dari pengamatan gambar strukutr mikro menggunakan mikroskop optik sampel yang mengalami perlakuan panas di atas temperatur sensitisasi yaitu pada suhu $950^{\circ} \mathrm{C}$ korosi, ternyata antar butir masih teramati tetapi tidak sejelas sampel yang mengalami perlakuan panas pada temperatur sensitisasi. 
4. Dari pengamatan menggunakan EDS diketahui bahwa sampel yang mengalami perlakuan panas dengan suhu $900^{\circ} \mathrm{C}$ waktu penahanan 3 jam dibandingkan dengan sampel yang mengalami perlakuan panas dengan suhu $900^{\circ} \mathrm{C}$ waktu penahanan $3 \frac{1}{2}$ jam komposisi unsur karbon (C) dan krom $(\mathrm{Cr})$ pada batas butir mengalami penurunan yaitu dari $0,61 \%$ massa menjadi $0,47 \%$ massa untuk karbon (C) dan untuk khrom (Cr) dari $18,37 \%$ massa menjadi $17.76 \%$ massa.

\section{DAFTAR PUSTAKA}

1. TRETHEWEY, KR., CHAMBERLAIN J., 1991, Korosi Untuk Mahasiswa dan Rekayasawan, PT. Gramedia Pustaka Utama, Jakarta.

2. SURDIA, T., SAITO, S., 1992, Pengetahuan Bahan Tehnik, cetakan kedua, PT. Pradnya Paramita, Jakarta.

3. HERLANI, 2005, "Efek Implantasi Elemen Reaktif Y dan Ce terhadap sifat ketahanan Korosi Pelat Seng dan Baja Tahan Karat SS304", STTN BATAN Yogyakarta.

4. PURBOWATI, W., 2006, "Implantasi Ion Alumunium Pada Bahan Cor-Ten Steel Untuk Peningkatan ketahanan Korosi pada Temperatur Tinggi”, STTN BATAN Yogyakarta.

5. ADITYA M.S., 2007, "Pengaruh Inhibitor Hidrasin Terhadap Laju Korosi Baja Tahan Karat (SS) 304 dalam lingkungan Air, FeU3, dan NiCl2", STTN BATAN Yogyakarta.

6. KENYON, W., 1979, Dasar-Dasar Pengelasan, Erlangga, Jakarta.

7. FONTANA, M.G., 1986, Corrosion Engineering, Third Edition, McGraw-Hill Book Company, Singapore.

8. SCOTT, E.C., Kanda, F.A., 1962, The Nature Of Atoms dan Molecules ; A General Chemistry, Harper \& Row, New York.

9. DIETER, G.E., 1993, Metalurgi Mekanik Jilid 1, edisi ketiga, Erlangga, Jakarta.

10. VAN VLACK, LH., 1983, Ilmu dan Teknologi Bahan (Ilmu Logam dan Bukan Logam), Erlangga, Jakarta.

11. AMSTEAD, B.H., Ostwald, P.F., Begeman, M.L., 1981, Teknologi Mekanik, Erlangga, Jakarta.

12. http://www.lenn-biz.com, tanggal 28 April 2008 jam 17.38.

13. http://www.calphad.com/iron-carbon.html, tanggal 28 April 2008 jam 17.08.

14. http://www.eng.vt.edu/eng/materials/classes/MSE2094_NoteBook/ 96ClassProj/ experimental/ternary $2 . \mathrm{html}$ 
